\title{
Analisis Produksi dan Risiko Produksi Usahatani Cabai Rawit di Kecamatan Watunohu, Kabupaten Kolaka Utara
}

Muhtar Amina, dan Campina Illa Prihantini ${ }^{b}$

aFakultas Pertanian,Perikanan, dan Peternakan, Universitas Sembilanbelas November Kolaka, Indonesia. Email: muhtaramin71@yahoo.com

${ }^{b}$ Fakultas Pertanian,Perikanan, dan Peternakan, Universitas Sembilanbelas November Kolaka, Indonesia. Email: campinailla26@gmail.com

\section{Article Info}

Article history:

Received 12 Desember 2020

Received in revised form 27 Desember 2020

Accepted 4 Januari 2021

DOI:

https://doi.org/10.32938/ag.v6i1.1199

\section{Keywords:}

Cayenne Pepper

Production

Production Risk

\begin{abstract}
Abstrak
This study aims to determine the factors that influence the production of cayenne pepper farming and the risks of cayenne pepper farming in Watunohu District, North Kolaka Regency. The number of respondents used in this study are 30 cayenne pepper farmers who were determined based on the snowballing sampling technique. The research method used was a field survey. Then, the survey results are used in linear regression analysis and risk analysis of chili farming using the SPSS application. The results of the study showed that there are three dependent variables that had a significant effect on the production of cayenne pepper. They are land area, seeds, and urea fertilizer. The risk of cayenne pepper farming in Watunohu District, North Kolaka Regency is in the low category as indicated by the coefficient of variance of 0.32. This means that in 100 times the production process, the chance of a production risk is 32 times the expected amount of cayenne pepper production.
\end{abstract}

\section{Pendahuluan}

Cabai rawit merupakan salah satu komoditas hortikultura yang lumrah dibudidayakan oleh petani di Indonesia. Harga jual yang tinggi merupakan alasan utama petani banyak membudidayakan tanaman ini (Haki dan Taena, 2017). Selain itu, cabai memiliki beberapa manfaat kesehatan. Salah satunya berfungsi dalam mengendalikan kanker karena mengandung lasparaginase dan capcaicin. Kandungan vitamin C yang cukup tinggi pada cabai dapat memenuhi kebutuhan harian setiap orang, namun harus dikonsumsi secukupnya untuk menghindari nyeri lambung (Swatika et al., 2017). Selain sebagai bumbu masak, industri makanan dan untuk peternakan juga memanfaatkan buah cabai sebagai bahan campuran (Setiadi, 2006).

Kabupaten Kolaka Utara merupakan kabupaten yang terletak di paling utara Provinsi Sulawesi Tenggara. Kabupaten ini merupakan kabupaten perbatasan dengan Provinsi Sulawesi Selatan dan Provinsi Sulawesi Tengah. Berbagai macam tanaman hortikultura baik sayuran maupun buah-buahan banyak ditanam di daerah ini. Salah satunya adalah tanaman cabai rawit. Kecamatan Watunohu merupakan salah satu kecamatan penghasil cabai rawit di Kabupaten Kolaka Utara (BPS Kabupaten Kolaka Utara, 2019). Pada tahun 2018, telah terjadi peningkatan luas panen tanaman cabai rawit hingga 200 persen. Hal ini menyebabkan terjadinya peningkatan produksi cabai rawit yang signifikan di tahun 2018. Terbukti pada tahun tersebut, kecamatan ini mampu menghasilkan cabai rawit sebanyak 66,00 kwintal. Hal ini dapat dikatakan bahwa telah terjadi peningkatan hasil produksi hingga 288 persen. Data mengenai luas panen dan produksi tanaman cabai rawit di Kecamatan Watunohu, Kabupaten Kolaka Utara pada tahun 2016 hingga tahun 2018 terdapat pada Tabel 1.

Tabel 1. Data Luas Panen dan Produksi Cabai Rawit Di Kecamatan Watunohu, Kabupaten Kolaka Utara Tahun 2016-2018

\begin{tabular}{lccc}
\hline \multicolumn{1}{c}{ Variabel } & \multicolumn{3}{c}{ Tahun } \\
\cline { 2 - 4 } & 2016 & 2017 & 2018 \\
\hline Luas Panen (Ha) & 3,00 & 4,00 & 12,00 \\
Produksi (Kwintal) & 80,00 & 17,00 & 66,00
\end{tabular}

Sumber : BPS Kabupaten Kolaka Utara, 2019

Terjadinya peningkatan produksi cabai rawit di tahun 2018 menjadi suatu hal yang menarik untuk dikaji dan diteliti. Terlebih, tanaman cabai rawit memiliki risiko produksi yang cukup tinggi karena masih sangat dipengaruhi oleh iklim dan cuaca serta faktor alam lainnya, sehingga perlu dianalisis mengenai risiko produksi cabai rawit di Kecamatan Watunohu, Kabupaten Kolaka Utara. Penelitian ini bertujuan untuk mengetahui faktor-faktor yang mempengaruhi produksi cabai rawit dan risiko usahatani cabai rawit di Kecamatan Watunohu, Kabupaten Kolaka Utara. 


\section{Metode}

Penelitian ini dilakukan di Kecamatan Watunohu, Kabupaten Kolaka Utara selama delapan bulan, yakni bulan Januari hingga Agustus 2020. Seluruh responden yang digunakan adalah 30 orang petani cabai rawit. Metode penentuan responden adalah dengan menggunakan teknik snowballing sampling. Tim peneliti mendatangi instansi terkait dengan menanyakan daerah penghasil cabai rawit terbesar kemudian mendatangi kantor kecamatan dan melakukan wawancara terkait dengan topik penelitian. Data penelitian terbagi menjadi data primer dan sekunder. Data primer merupakan hasil wawancara melalui kuesioner cabai rawit di Kecamatan Watunohu, Kabupaten Kolaka Utara. Data sekunder diperoleh dari instansi terkait, seperti BPS, buku, bahan bacaan primer berupa artikel jurnal, berita, dan lainnya yang berhubungan dengan topik penelitian.

\subsection{Analisis Faktor-Faktor Yang Mempengaruhi Produksi Usahatani Cabai Rawit Di}

Kecamatan Watunohu, Kabupaten Kolaka Utara

Analisis ini digunakan untuk mengetahui pengaruh dari setiap faktor produksi yang digunakan terhadap hasil produksi cabai rawit di Kecamatan Watunohu, Kabupaten Kolaka Utara. Tim peneliti menggunakan program SPSS versi 21 untuk menentukan persamaan regresi linear berganda. Persamaan linear berganda mengikuti persamaan berikut ini.

$$
\ln Y=\ln a+\beta_{1} \ln X_{1}+\beta_{2} \ln X_{2}+\beta_{3} \ln X_{3}+\beta_{4} \ln X_{4}+\beta_{5} \ln X_{5}
$$

Keterangan :

$$
\begin{array}{ll}
\mathrm{a} & =\text { Intercept } \\
\beta & =\text { Koefisien Regresi } \\
\mathrm{Y} & =\text { Produksi } \\
\mathrm{X}_{1} & =\text { Luas Lahan } \\
\mathrm{X}_{2} & =\text { Benih } \\
\mathrm{X}_{3} & =\text { Pupuk Kandang } \\
\mathrm{X}_{4} & =\text { Pupuk Urea } \\
\mathrm{X}_{5} & =\text { Tenaga Kerja }
\end{array}
$$

\subsection{Analisis Risiko Produksi Usahatani Cabai Rawit Di Kecamatan Watunohu Kabupaten} Kolaka Utara.

Analisis ini digunakan untuk mengetahui tingkat risiko produksi tanaman cabai rawit yang ditanama oleh petani di Kecamatan Watunohu, Kabupaten Kolaka Utara. Tim peneliti melakukan analisis risiko dengan mengalikan nilai koefisien variasi (CV) dengan $100 \%$. Semakin tinggi nilai CV maka semakin tinggi tingkat risiko yang dialami usahatani cabai rawit. Klasifikasi tingkat risiko dapat dilihat pada Tabel 2.

Tabel 2. Tingkat Risiko Berdasarkan Nilai Koefisien Variasi (CV)

\begin{tabular}{lc}
\hline \multicolumn{1}{c}{ Tingkat Resiko } & Nilai CV (\%) \\
\hline Sangat Tinggi & $81-100$ \\
Tinggi & $61-80$ \\
Sedang & $41-60$ \\
Rendah & $21-40$ \\
Sangat rendah & $0-20$ \\
\hline
\end{tabular}

Sumber : Abdullah, 2015

\section{Hasil dan Pembahasan}

3.1. Karakteristik Petani Cabai Rawit Di Kecamatan Watunohu, Kabupaten Kolaka Utara

Karakteristik petani cabai di Kecamatan Watunohu, Kabupaten Kolaka Utara memiliki keanekaragaman. Hal ini mempengaruhi bagaimana pengambilan keputusan dalam usahatani cabai rawit yang dijalankannya. Misalnya, penggunaan pupuk yang akan diberikan, penggunaan tenaga kerja baik dari dalam maupun dari luar keluarga, jenis bibit dan benih yang akan digunakan, pelaksanaan awal tanam, dan bagaimana cara meghindari atau menghadapi risiko produksi usahatani cabai rawit. Karakteristik petani cabai rawit dikelompokkan menjadi empat dalam Tabel 3.

Berdasarkan Tabel 3 di atas, usia rata-rata petani cabai rawit adalah 41,5 tahun. Usia ini termasuk dalam kategori produktif di Indonesia, yakni 15 ingga 64 tahun. Hal ini berpengaruh terhadap produktivitas petani dalam menghasilkan cabai rawit dalam satu musim tanam. Umur berpengaruh signifikan terhadap produktivitas usahatani minapadi (Sujaya et al.,2018). Musafiri 
(2016) menyatakan bahwa petani yang berumur muda lebih termotivasi, inovatif dan Rata-rata petani cabai rawit di kecamatan ini lulusan. Sekolah Menengah Pertama (SMP) dan/atau Sekolah Menengah Atasa (SMA). Bahkan hanya 1 orang saja yang menjadi lulusan Strata-1 (S-1). Ratarata pengalaman bertani para petani adalah 2,6 tahun. Artinya, mereka sudah memiliki pengalaman yang banyak dalam usahatani cabai rawit. Rata-rata jumlah tanggungan keluarga adalah 3,9 atau 4 orang. Angka ini menunjukkan bahwa rata-rata tanggungan petani cukup tinggi. Sehingga usahatani cabai rawit yang dilakukannya menjadi harapan dalam pemenuhan kebutuhan keluarga.

Tabel 3. Karakteristik Petani Cabai Rawit Di Kecamatan Watunohu, Kabupaten Kolaka Utara Tahun 2020

\begin{tabular}{|c|c|c|}
\hline Kategori Usia & Jumlah & Persentase \\
\hline$<15$ Tahun & 3 & 10 \\
\hline 15- 64 Tahun & 24 & 80 \\
\hline$>64$ Tahun & 3 & 10 \\
\hline Jumlah & 30 & 100 \\
\hline Usia Rata-rata & 41,5 Tahun & \\
\hline \multicolumn{3}{|c|}{ Kategori Tingkat Pendidikan terakhir } \\
\hline Tidak Tamat SD & 3 & 10 \\
\hline Tamat SMP-SMA & 26 & 86,67 \\
\hline Lulusan S1 & 1 & 3,33 \\
\hline Jumlah & 30 & 100 \\
\hline \multicolumn{3}{|l|}{ Kategori Pengalaman Bertani } \\
\hline$<1$ Tahun & 3 & 10 \\
\hline $1-3$ Tahun & 10 & 33,33 \\
\hline$>3$ Tahun & 17 & 57,67 \\
\hline Jumlah & 30 & 100 \\
\hline Pengalaman Bertani Rata-rata & 2,6 Tahun & \\
\hline \multicolumn{3}{|c|}{ Kategori Jumlah Tanggungan Keluarga } \\
\hline $1-3$ Orang & 13 & 43,33 \\
\hline 4 - 6 Orang & 16 & 53,33 \\
\hline > 6 Orang & 1 & 3,33 \\
\hline Jumlah & 30 & 100 \\
\hline $\begin{array}{l}\text { Jumlah Tanggungan Keluarga } \\
\text { Rata-rata }\end{array}$ & 3,9 Orang & \\
\hline
\end{tabular}

Sumber : Data Primer Diolah, 2020

3.2. Faktor-Faktor Yang Mempengaruhi Produksi Usahatani Cabai Rawit Di Kecamatan Watunohu, Kabupaten Kolaka Utara

Analisis ini bertujuan untuk melihat dan menganalisis faktor-faktor yang memengaruhi produksi cabai rawit di Di Kecamatan Watunohu Kabupaten Kolaka Utara. Hasil regresi yang dilakukan dengan menggunakan software SPSS versi 2.1 tersaji dalam Tabel 4.

3.3. Analisis Uji Koefisien Determinasi $\left(\mathrm{R}^{2}\right)$

Berdasarkan Tabel 4, koefisien determinasi $\left(\mathrm{R}^{2}\right)$ sebesar 0,971 atau mencapai 97,1\% angka tersebut menunjukkan bahwa kemampuan variabel bebas dalam memberikan informasi untuk menjelaskan keragaman variabel terikat relatif besar. Hasil tersebut dapat disimpulkan bahwa model hasil produksi cabai rawit di kecamatan ini mampu dijelaskan oleh variabel independen (luas lahan, benih, pupuk kandang, pupuk urea, dan tenaga kerja) sebesar 97,1 persen. Sedangkan sisanya sebesar 2.9 persen model produksi cabai rawit dijelaskan oleh variabel di luar model, misalnya pestisida, iklim, dan/atau cuaca.

\subsection{Analisis Uji Keragaman (Uji F)}

Analisis Uji F digunakan untuk mengetahui apakah variabel independen (luas lahan, benih, pupuk kandang, pupuk urea dan tenaga kerja) secara simultan (bersama-sama) berpengaruh terhadap variabel dependen (produksi). Jika Fhitung > FTabel maka variabelvariabel independen tersebut mempunyai pengaruh yang signifikan terhadap variabel dependen. Sedangkan jika Fhitung < FTabel maka variabel-variabel independen mempunyai pengeruh yang tidak signifikan terhadap variabel dependen.

Berdasarkan hasil uji F dalam Tabel 4 diatas, diperoleh nilai Fhitung sebesar 159,240 lebih besar dari FTabel sebesar 2,62 dengan tingkat kepercayaan 95\% $(a=0.05)$ 
dengan nilai dfNI $=5$ dan df $\mathrm{N} 2=23$, maka $\mathrm{H}_{1}$ diterima dan $\mathrm{H}_{0}$ ditolak yang berarti bahwa variabel luas lahan, benih, pupuk, dan tenaga kerja secara simultan (bersama-sama) berpengaruh signifikan terhadap produksi.

Tabel 4. Hasil Regresi Analisis Faktor-Faktor yang Mempengaruhi Produksi Usahatani Cabai Rawit Di Kecamatan Watunohu, Kabupaten Kolaka Utara Tahun 2020

\begin{tabular}{lrrr}
\hline \multicolumn{1}{c}{ Variabel } & Koefisien & t hitung. & Sign \\
\hline Konstanta & 4.226 & $7.673^{* *}$ & 0.000 \\
Luas lahan & 0.846 & $4.612^{* *}$ & 0.000 \\
Benih & -0.042 & $-2,425^{* *}$ & 0.023 \\
Pupuk kandang & 0.199 & 0.285 & 0.778 \\
Pupuk urea & -0.138 & $-2.594^{* *}$ & 0.016 \\
Tenaga kerja & -0.056 & -0.112 & 0.912 \\
\hline R-Squarred & 0,971 & & \\
Fhitung & 159.240 & & \\
FTabel & 2,62 & & \\
TTabel & 1,710 & & \\
$\mathrm{~N}$ & 30 & &
\end{tabular}

Sumber : Data Primer Diolah, 2020

\subsection{Analisis Koefisien Regresi (Uji t)}

Dalam persamaan regresi suatu penelitian nilai koefisien pada masing- masing variabel independen (luas lahan, benih, pupuk kandang, pupuk urea, dan tenaga kerja) melalui pengujian menggunakan SPSS Versi 21. Hal ini bertujuan untuk mengetahui variabel independen yang mana yang memiliki pengaruh signifikan terhadap variabel dependen (produksi). Berdasarkan hasil regresi pada Tabel 4 di atas, diperoleh persamaan regresi sebagai berikut.

$$
\begin{aligned}
& \ln Y=\ln a+\beta_{1} \ln X_{1}+\beta_{2} \ln X_{2}+\beta_{3} \ln X_{3}+\beta_{4} \ln X_{4}+\beta_{5} \ln X_{5} \ldots \ldots \ldots \ldots \ldots \ldots \ldots \ldots \ldots \ldots \\
& Y \quad=4.226+0.846 X_{1}-0.042 X_{2}+0.199 X_{3}-0.138 X_{4}-0.056 X_{5}
\end{aligned}
$$

\section{Luas lahan (X1)}

Hasil regresi pada Tabel 4, menunjukkan bahwa variabel luas lahan mempunyai nilai koefisien regresi sebesar 0,846 dan nilai thitung 4,612 lebih besar tTabel 1,710 dan sign $0.000<0.05$ artinya berada pada daerah penerimaan, $\mathrm{H}_{0}$ ditolak $\mathrm{H}_{1}$ diterima. Sehingga dapat disimpulkan bahwa luas lahan berpengaruh signifikan dengan nilai koefisien sebesar 0.846 hal ini menunjukkan bahwa penambahan luas lahan garapan 1\% akan menambah produksi cabai rawit sebesar 0,846\%. Hal ini dikarenakan semakin besar luas lahan akan memperbesar potensi produksi yang akan memperbesar penerimaan usahatani cabai rawit dan meningkatkan produksi (Pranata dan Damayanti 2016). Hasil kajian ini sesuai dengan fakta di lapangan. Data pada BPS Kabupaten Kolaka Utara (2019) menyebutkan bahwa telah terjadi penambahan luas panen tanaman cabai rawit pada tahun 2018 sehingga hasil produksi cabai rawit juga meningkata di tahun 2018. Berbeda dengan hasil kajian yang dilakukan oleh Bete dan Taena (2018). Berdasarkan hasil analisis, luas lahan tidak berpengaruh nyata terhadap produksi cabe rawit merah. Hal ini terjadi karena petani yang mengusahakan cabe rawit merah dengan luas lahan yang relatif sama (berukuran kecil 9-25 are).

\section{Benih (X2)}

Hasil regresi pada Tabel 4, menunjukkan bahwa variabel benih mempunyai nilai koefisien regresi negatif sebesar -0,042 dan nilai thitung -2,425 lebih besar t-Tabel 1,710 dan nilai sign $0.023<0.05$ pada tingkat kesalahan $5 \%$. Artinya berada pada daerah penerimaan, $\mathrm{H}_{0}$ ditolak $\mathrm{H}_{1}$ diterima. Sehingga dapat disimpulkan bahwa benih berpengaruh signifikan dengan nilai koefisien sebesar -0.042, artinya penambahan benih sebesar $1 \%$ akan mengurangi produksi cabai rawit, sebesar -0,042. Hasil kajian ini berbeda dengan hasil kajian yang dilakukan oleh Fanani et al., (2019) yang mana bibit dan hasil produksi cabai rawit memiliki hubungan yang positif.hubungan yang positif antara benih dan hasil produksi juga dinyatakan oleh Sarina et a.,. (2015).

\section{Pupuk Kandang (X3)}

Pada Tabel 4 menunjukkan bahwa variabel pupuk kandang mempunyai nilai koefisien regresi sebesar 0,199 dan nilai thitung 0,285 lebih kecil tTabel 1,710 dan sign $0.778>0.05$ 
pada tingkat kesalahan 5\%. artinya berada pada daerah penerimaan, $\mathrm{H}_{0}$ diterima $\mathrm{H}_{1}$ ditolak. Sehingga dapat disimpulkan bahwa pupuk kandang tidak berpengaruh signifikan dengan nilai koefisien sebesar 0.199. Hal ini menunjukkan bahwa setiap penambahan $1 \%$ pupuk kandang akan menambah produksi sebesar 0,199\%. Rata-rata pemakaian pupuk kandang selama masa tanam adalah sebesar 697 kilogram. Hasil kajian yang dilakukan oleh tim peneliti berbeda dengan hasil kajian yang dilakukan oleh Fanani et al., (2019). Dalam penelitiannya ternyata pemakaian pupuk kandang justru berdampak negatif terhadap hasil produksi cabai rawit yang ditanam di Kecamatan Bancar, Kabupaten Tuban. Namun, baik kajian tim peneliti maupun Fanani et al. menyebutkan bahwa pupuk kandang tidak berdampak nyata terhadap hasil produksi cabai rawit di masing-masing tempat penelitian.

\section{4. $\quad$ Pupuk Urea (X4)}

Berdasar pada Tabel 4 menunjukkan bahwa variabel pupuk Urea mempunyai nilai koefisien regresi negatif sebesar $-0,138$ dan nilai thitung -2,594 lebih besar t-Tabel 1,710 dan sign $0.016<0.05$ pada tingkat kesalahan 5\%. artinya berada pada daerah penerimaan, $\mathrm{H}_{0}$ ditolak $\mathrm{H}_{1}$ diterima. Sehingga dapat disimpulkan bahwa pupuk Urea berpengaruh signifikan dengan nilai koefisien sebesar -0138. Hal ini menunjukkan bahwa setiap penambahan $1 \%$ pupuk Urea akan mengurangi produksi sebesar -0,138\%. Rata-rata penggunaan pupuk Urea di Kecamatan Watunohu adalah64,7 kilogram dalam satu musim tanam. Pengaruh penggunaan pupuk Urea di penelitian yang dilakukan oleh Fanani et al., (2019) ternyata sama dengan yang dilakukan oleh tim peneliti. Hanya saja pada penelitian yang dilakukan oleh Fanani et al., (2019) pupuk Urea tidak memberikan pengaruh yang nyata terhadap produksi cabai rawit.

\section{Tenaga Kerja (X5)}

Dalam Tabel 4 menunjukkan bahwa variabel tenaga kerja mempunyai nilai koefisien regresi negatif sebesar -0,056 dan nilai thitung -0,529 lebih kecil t-Tabel 1,710 pada tingkat kesalahan 5\%. Artinya berada pada daerah penerimaan, $\mathrm{H}_{0}$ diterima $\mathrm{H}_{1}$ ditolak. Sehingga dapat disimpulkan bahwa tenaga kerja berpengaruh tidak signifikan dengan nilai koefisien sebesar -0.056. Hal ini menunjukkan bahwa setiap penambahan $1 \%$ tenaga kerja akan mengurangi produksi sebesar -0,056\%. Maka dapat di simpulkan bahwa semakin banyak tenaga kerja yang digunakan petani cabai rawit tidak akan mempengaruhi produksi. Hal ini disebabkan oleh banyak ataupun sedikitnya jumlah tenaga kerja yang dipekerjakan pada lahan pertanian tidak menjadi patokan utama dalam meningkatkan produksi cabai rawit yang dihasilkkan. Justru faktor keahlian dan keuletan para tenaga kerja yang berpengaruh terhadap hasil produksi cabai rawit..

Bete dan Taena (2018) menjelaskan bahwa tenaga kerja sangat berpengaruh positif dan sangat nyata terhadap produksi cabe rawit merah. Semakin banyak tenaga kerja yang digunakan pada tahap tertentu usahatani akan menyebabkan tenaga kerja tersebut menggunakan waktu dan tenaga secara tidak efisien. Hal ini juga sesuai dengan kajian yang dilakukan oleh Apriana (2017) dan Fanani et al., (2019).

\subsection{Risiko Produksi Usahatani Cabai Rawit Di Kecamatan Watunohu, Kabupaten Kolaka Utara}

Risiko adalah peluang terhadap suatu kejadian yang dapat diketahui oleh pelaku bisnis sebagi pembuat keputusan berdasarkan kejadian serupa yang pernah terjadi pada masa sebelumnya sehingga hasil dari keputusan terhadap kejadian sebelumnya dapat digunakan untuk mengestimasikan peluang kejadian berikutnya. Risiko produksi merupakan kerugian pada petani yang disebabkan oleh timbulnya proses produksi yang tidak dapat ditangani. Proses produksi harus menyesuaikan antara output yang akan dicapai dengan input yang tepat melalui teknologi tepat guna, sehingga akan mengurangi dampak kerugian (Rodjak, 2002). Risiko produksi umumnya disebabkan oleh adanya faktor lingkungan (iklim, tanah dan temperatur) yang berpengaruh terhadap hasil produksi. Usaha di bidang pertanian, termasuk usahatani cabai rawit merupakan jenis usaha yang sangat rentan dengan risiko, khususnya risiko produksi (Fannai et al., 2019). Hal ini terjadi karena selain ditentukan penggunaan faktor-faktor produksi yang efektif dan efisien, jumlah produksi cabai rawit juga sangat ditentukan oleh keadaan alam, seperti iklim, kesuburan tanah dan kondisi temperatur suatu wilayah. Salah satu metode yang digunakan untuk mengukur tingkat risiko produksi pada sektor usahatani adalah dengan menggunakan nilai koefisien varians $(\mathrm{CV})$. Secara rinci, hasil analisis risiko produksi pada usahatani cabai rawit di lokasi penelitian disajikan pada Tabel 5.

Tabel 5 menunjukkan bahwa nilai koefisien varian produksi usahatani cabai rawit di Kecamatan Watunohu adalah sebesar 0,32 yang menunjukkan bahwa variabilitas nilai ratarata dengan tingkat risiko (Rendah) pada distribusi jumlah produksi yang dihasilkan. Nilai 
koefisien varian sebesar 0,32 memiliki makna bahwa dalam seratus kali proses produksi usahatani Cabai rawit, petani di lokasi penelitian memiliki peluang gagal panen sebanyak 32 kali dari jumlah produksi cabai rawit yang diharapkan. Risiko produksi pada usahatani cabai rawit di Kecamatan Watunohu sebagian besar disebabkan oleh serangan hama seperti hama busuk batang dan hama kutu daun, dimana kedua jenis hewan tersebut selalu menjadi perusak pada tanaman cabai rawit milik petani, sehingga menghilangkan potensi petani cabai rawit untuk meraih jumlah produksi yang maksimal.

Tabel 5. Analisis Risiko Produksi Usahatani Cabai Rawit di Kecamatan Watunohu Kabupaten Kolaka Utara Tahun 2020

\begin{tabular}{clcc}
\hline No. & Uraian & Satuan $(\mathrm{Kg})$ & Nilai \\
\hline 1 & Rata-rata produksi & $\mathrm{Kg}$ & 18,768 \\
2 & Standar deviasi produksi & $\mathrm{Kg}$ & 6,069 \\
3 & Koevisien Varian Produksi & $\mathrm{Kg}$ & 0,32 \\
\hline
\end{tabular}

Sumber : Data Primer Diolah, 2020

Hasil penelitian ini sesuai dengan hasil kajian yang dilakukan oleh Alfianor (2018) yang mana risiko produksi usahatani cabai rawit di Desa Malilingin, Kecamatan Padang Batung, Kabupaten Hulu Sungai Selatan adalah sebesar 43 persen atau termasuk dalam kategori sedang. Risiko produksi terjadi pada saat serangan hama, penyakit, cuaca dan iklim sulit diprediksi serta kurangnya keahlian manajemen usahatani. Fanani et al., (2019) menjelaskan bahwa faktorfaktor yang mempengaruhi risiko produksi tanaman cabai rawit di Desa Bulujowo, Kecamatan Bancar, Kabupaten Tuban pada umumnya adalah serangan hama, penyakit, cuaca, iklim, luas lahan, serta benih.

\section{Simpulan}

Variabel luas lahan, benih, dan pupuk Urea berpengaruh signifikan terhadap produksi cabai rawit di Kecamatan Watunohu, Kabupaten Kolaka Utara. Variabel pupuk kandang dan tenaga kerja berpengaruh tidak signifikan terhadap produksi cabai rawit. Risiko produksi usahatani cabai rawit di Kecamatan Watunohu Kabupaten Kolaka Utara berada dalam kategori rendah yang ditunjukkan dengan nilai koefisien varian sebesar 0,32. Artinya, dalam 100 kali proses produksi, peluang terjadinya risiko produksi adalah sebesar 32 kali dari jumlah produksi cabai rawit yang diharapkan.

\section{Pustaka}

Abdullah, H.M.M. 2015. Metodologi Penelitian Kuantitatif (Untuk: Ekonomi, Manajemen, Komunikasi, dan Ilmu Sosial Lainnya). Yogyakarta (ID) : Aswaja Pressindo.

Alfianor. 2018. Analisis Risiko Produksi Tanaman Cabai Rawit Di Desa Malilingin Kecamatan Padang Batung Kabupaten Hulu Sungai Selatan [Skripsi]. Banjarmasin (ID): Universitas Lambung Mangkurat. http://digilib.ulm.ac.id/archive/digital/detailed.php?code=2750.

Apriana, N., Fariyanti, A., dan Burhanuddin. 2017. Preferensi Risiko Petani Padi Daerah Aliran Sungai Bengawan Solo Kabupaten Bojonegoro Provinsi Jawa Timur. Jurnal Management Dan Agribisnis. 14 (2) : 165-173.

Bete, K., dan Taena, W. 2018. Faktor-Faktor yang Mempengaruhi Produksi Usahatani Cabe Rawit Merah di Desa Tapenpah Kecamatan Insana Kabupaten Timor Tengah Utara. Agrimor. 3 (1) : 7-9.

[BPS] Badan Pusat Statistik. 2019. Kabupaten Kolaka Utara Dalam Angka tahun 2019. BPS Press. https://kolutkab.bps.go.id/.

Fanani, I.H., Siswadi, B., dan Syakir, F. 2019. Perilaku Petani Cabai Rawit Terhadap Risiko Produksi Di Desa Bulujowo Kecamatan Bancar Kabupaten Tuban. SEAGRI . 7 (4). http:// riset.unisma.ac.id/index.php/SEAGRI/article/view/4607/4155.

Haki, M.G. dan Taena, W. 2017. Analisis Pendapatan Usahatani Cabe Rawit Merah di Desa Tapenpah Kecamatan Insana Kabupaten Timor Tengah Utara. AGRIMOR, 2(04): 57-58.

Musafiri, I. 2016. Effects of Population Growth on Smallholder Farmers' Productivity and Consumption in Rwanda: A Long-term Analysis. Asian Journal of Agricultural Extension, Economics \& Sociology. 12(4): 1-11. DOI: 10.9734/AJAEES/2016/27693.

Pranata, G.W. dan Damayanti, L. 2016. Faktor-Faktor Yang Memengaruhi Produksi Usahatani Cabai Merah Kriting Di Desa Bulupountu Jaya Kecamatan Sigi Biromaru Kabupaten Sigi . Agroland. 23 (1) : $11-19$.

Rodjak, A. 2002. Manajemen Usahatani. Bandung (ID) : Pustaka Giratuna. 
Sarina, Silamat, E., dan Puspitasari, D. 2015. Analisis Faktor- Faktor Yang Mempengaruhi Produksi Cabai Merah Di Desa Kampung Melayu Kecamatan Bermani Ulu Kabupaten Rejang Lebong. Jurnal Agroqua. 13(2): 57-67.

Setiadi. 2006. Cabai Rawit Jenis dan Budaya. Jakarta (ID): Penebar Swadaya.

Sujaya, D.H., Hardiyanto. H., dan Isyanto. A.Y. 2018. Faktor-Faktor Yang Berpengaruh Terhadap Produktivitas Usahatani Mina Padi Di Kota Tasikmalaya. Mimbar Agribisnis: Jurnal Pemikiran Masyarakat Ilmiah Berwawasan Agribisnis. 4(1): 25-39.

Swatika, S., Pratama, D., Hidayat, T., dan Andri, K.B. 2017. Buku Petunjuk Teknis Teknologi Budidaya Cabai Merah Besar. Pekanbaru (ID): Badan Penerbit Universitas Riau UR PRESS. 